\title{
Review
}

\section{Regulatory T Cells, a Potent Immunoregulatory Target for CAM Researchers: Modulating Allergic and Infectious Disease Pathology (II)}

\author{
Aristo Vojdani and Jonathan Erde \\ Immunosciences Lab., Inc., 8693 Wilshire Boulevard, Suite 200, Beverly Hills, CA 90211, USA
}

Regulatory $\mathrm{T}\left(\mathrm{T}_{\text {reg }}\right)$ cells maintain dominant control of immune responses to foreign materials and microbes. Appropriate $\mathrm{T}_{\text {reg }}$ cell suppression of immune responses is essential for the maintenance of efficacious defensive responses and the limitation of collateral tissue damage due to excess inflammation. Allergy and infection are well studied and frequent afflictions in which $\mathrm{T}_{\text {reg }}$ cells play an essential role. As such, they provide excellent models to communicate the significance and relevance of $\mathrm{T}_{\text {reg }}$ cells to complementary and alternative medicine (CAM).

\section{$T_{\text {reg }}$ Ubiquity and Universality: Relations to Foreign Bodies}

The major principles underlying the dynamic immune system, including constituents, interrelationships and feedback mechanisms have been established, with emphasis on regulatory $\mathrm{T}\left(\mathrm{T}_{\text {reg }}\right)$ cells (1). The goal of this article is (i) to detail $\mathrm{T}_{\text {reg }}$ cells, (ii) to delineate $\mathrm{T}_{\text {reg }}$ cell function in allergy and infection and (iii) to examine the pathological consequences of aberrant $\mathrm{T}_{\text {reg }}$ cell activity. Allergy and infection are wellstudied and frequent afflictions, and as such, they provide excellent models to communicate the significance and relevance of $\mathrm{T}_{\text {reg }}$ cells to complementary and alternative medicine (CAM).

Considerable inflammation, resulting from allergic hypersensitivity or immune response to infection, has the potential to induce deleterious effects on an individual's tissues and overall well-being. Recent evidence has served to elucidate the mechanism of action and substantiate the usage of a veritable array of traditional herbs, folk medicines and other compounds found in nature, which have been employed to attenuate inflammatory complications. Of interest to

For reprints and all correspondence: Aristo Vojdani,

Immunosciences Lab., Inc., Section of Neuroimmunology,

8693 Wilshire Boulevard, Suite 200, Beverly Hills, CA 90211, USA.

Tel: +1-310-657-1077; Fax: +1-310-657-1053;

E-mail: immunsci@ix.netcom.com practitioners, researchers and patients of CAM modalities are those compounds that maintain powerful immunomodulatory capacity via direct or indirect action on $\mathrm{T}_{\text {reg }}$ cells (Table 1 ).

A cornucopia of herbal medicines has shown clinical effectiveness in the attenuation of allergic and infection-induced inflammatory pathology. Traditional therapeutics for allergic complications includes immunotherapy, antihistamines and glucocorticoids. A newly researched compound, termed antiasthma herbal medicine intervention (ASHMI), which is an extract of three herbs, has shown effectiveness and benefit over traditional treatment options for asthma. ASHMI mainly downregulates $\mathrm{T}_{\mathrm{H}} 2$ cell responses, increases lung function through direct modulation of smooth muscle contraction and decreases peripheral blood eosinophils and serum IgE. ASHMI does not induce a state of general immunosuppression like steroids, such as prednisone, which suppress $T_{H} 1$ and $T_{H} 2$ cell responses.

Treatment of infection with antimicrobial drugs poses an array of complications, including resistance and physical ailments, e.g. diarrhea. Allium sativum, extracted from garlic, has the potential to bolster $\mathrm{T}_{\mathrm{H}} 1$ cell-mediated responses to pathogens, such as Leishmania major. The proposed mechanism includes enhancement of $\mathrm{T}_{\mathrm{H}} 1$ cytokine response, T lymphocyte proliferation and NK cell activity. This method of antimicrobial treatment offers benefits over pharmaceutical drugs; however, its efficacy and mechanism of action needs further research and elucidation.

(C) The Author (2006). Published by Oxford University Press. All rights reserved.

The online version of this article has been published under an open access model. Users are entitled to use, reproduce, disseminate, or display the open access version of this article for non-commercial purposes provided that: the original authorship is properly and fully attributed; the Journal and Oxford University Press are attributed as the original place of publication with the correct citation details given; if an article is subsequently reproduced or disseminated not in its entirety but only in part or as a derivative work this must be clearly indicated. For commercial re-use, please contact journals.permissions@oxfordjournals.org 
Table 1. CAM compounds with regulatory capability and utility in Allergy and Infection

\begin{tabular}{|c|c|c|}
\hline Natural product & Activity & Reference \\
\hline \multirow[t]{2}{*}{ Brazilian green propolis } & $\begin{array}{l}\text { Modulate initial } \\
\text { inflammation }\end{array}$ & $(2,3)$ \\
\hline & Lower parasitemia & \\
\hline \multirow{3}{*}{$\begin{array}{l}\text { Ganoderma lucidum } \\
\text { (mycelia extract) }\end{array}$} & Activate $\kappa \mathrm{B}$ DNA binding & $(4,5)$ \\
\hline & Increase TNF- $\alpha$, IL- 6 , IFN- $\gamma$ & \\
\hline & Inhibit histamine release & \\
\hline \multirow[t]{2}{*}{$\begin{array}{l}\text { Phellinus linteus } \\
\text { (mycelia extract) }\end{array}$} & $\begin{array}{l}\text { Lower TNF- } \alpha \text {, IFN- } \gamma \\
\text { production }\end{array}$ & (6) \\
\hline & Lower IgG levels & \\
\hline \multirow[t]{2}{*}{ Piper methysticum (kava) } & Inhibit TNF- $\alpha$ release & (7) \\
\hline & Induce NF- $\kappa \mathrm{B}$ transcription & \\
\hline \multirow[t]{3}{*}{ Allium sativum (garlic) } & $\begin{array}{l}\text { Increase } T_{H} 1 \text { cytokine } \\
\text { response }\end{array}$ & (8) \\
\hline & $\begin{array}{l}\text { Enhance macrophage and } \\
\text { NK cell activity }\end{array}$ & \\
\hline & Increase $\mathrm{T}$ cell proliferation & \\
\hline \multirow[t]{2}{*}{$\begin{array}{l}\text { (-)-epigallocatechin } \\
\text { gallate (green tea) }\end{array}$} & $\begin{array}{l}\text { Decrease IL-2, IFN- } \gamma \text {, } \\
\text { TNF- } \alpha \text { levels }\end{array}$ & (9) \\
\hline & Decrease $\mathrm{T}$ cell proliferation & \\
\hline Probiotics & Induce $\mathrm{T}_{\mathrm{r}} 1$ and $\mathrm{T}_{\mathrm{H}} 3$ induction & $(10-14)$ \\
\hline Lactobacillus casei & Propogates oral tolerance & \\
\hline $\begin{array}{l}\text { BGN4 (Bifidobacterium } \\
\text { bifidum) }\end{array}$ & $\begin{array}{l}\text { Decreases } \operatorname{Ig} \mathrm{A} \text { and } \operatorname{IgE} \\
\text { production }\end{array}$ & \\
\hline \multirow[t]{2}{*}{ VSL \#3 } & $\begin{array}{l}\text { Dampens NF- } \mathrm{\kappa B} \\
\text { proinflammatory signals }\end{array}$ & \\
\hline & $\begin{array}{l}\text { Decreases levels of cell } \\
\text { degranulation }\end{array}$ & \\
\hline Staphyloccocal superantigen B & $\mathrm{T}_{\text {reg }}$ cell suppressor & $(2,15)$ \\
\hline $\begin{array}{l}\text { Ergosterol peroxide } \\
\text { (Tricholoma populinum) }\end{array}$ & Decreases allergic symptoms & (5) \\
\hline ASHMI & $\begin{array}{l}\text { Decreases TH2 response } \\
\text { and cytokines profile }\end{array}$ & $(16,17)$ \\
\hline Ganoderma lucidum & $\begin{array}{l}\text { Lowers IL-5, IL-13 and } \\
\text { IgE levels }\end{array}$ & \\
\hline \multicolumn{3}{|l|}{$\begin{array}{l}\text { Radix Sophora } \\
\text { flavescentis }\end{array}$} \\
\hline \multicolumn{3}{|l|}{$\begin{array}{l}\text { Radix Glycyrrhiza } \\
\text { uralensis }\end{array}$} \\
\hline KRN7000 & Immunostimulantion & (18) \\
\hline \multirow[t]{2}{*}{$\begin{array}{l}\text { Agelus mauritianus } \\
\text { derivative }\end{array}$} & $\begin{array}{l}\text { Increases IFN- } \gamma, \text { IL- } 4 \text {, } \\
\text { and IL-12 }\end{array}$ & \\
\hline & Enhances NK cell activity & \\
\hline
\end{tabular}

CAM benefits greatly from research done to determine a scientific basis for confident treatment decisions, as it lends credibility to CAM modalities and, most importantly, offers efficacious treatment options to a large segment of the population afflicted with allergic and infectious complications. Knowledge of the dynamic relationship between $\mathrm{T}_{\text {reg }}$ cells and immune system responses to foreign antigens is essential in order to approach $\mathrm{T}_{\text {reg }}$ cells as a clinical target for the alleviation of complications arising from allergy, asthma, dermatitis and infection.

\section{$T_{\text {reg }}$ Subsets: Three of a Kind}

The family greatly responsible for immunomodulation consists of two key subsets: naturally arising and peripherally induced $\mathrm{T}_{\text {reg }}$ cells. Although the ontogenic relationship between the two is not well understood, both subsets have been characterized by distinct differentiation patterns and functions (19).

\section{Naturally Occurring $\mathbf{T}_{\text {reg }}$ Cells}

Naturally occurring $\mathrm{T}_{\text {reg }}\left(\mathrm{nT}_{\text {reg }}\right)$ cells compose $5-10 \%$ of peripheral $\mathrm{T}$ cells, maintain a distinct lineage and develop in the thymus. $\mathrm{nT}_{\text {reg }}$ cells are directed to largely aid in tolerance to self-antigen in the periphery via suppressive actions on both $\mathrm{T}_{\mathrm{H}} 1$ and $\mathrm{T}_{\mathrm{H}} 2$ cell-mediated immune responses, with greater specificity for the former (20-24).

$\mathrm{nT}_{\text {reg }}$ cells inhibitory action is contact dependent. Interaction of CTLA- 4 and TGF- $\beta 1$, expressed on the cell surface, with respective ligands and receptors on target cells, triggers the downregulation of effector cell IL-2R $\alpha$ receptors and a subsequent decrease in fitness $(20,23,25)$. Alternate mechanisms proposed include the perforin-dependent induction of $\mathrm{T}$ cell apoptosis and the reduction of dendritic cell's ability to prime $\mathrm{T}$ cells, through direct suppression of cytokine secretion or tryptophan metabolism $(2,15,26-28)$.

\section{Peripherally Induced $\mathbf{T}_{\text {reg }}$ Cells}

The adaptive $T_{\text {reg }}$ cell subset includes type $1 T_{\text {reg }}\left(T_{r} 1\right)$ cells and $T$ helper $3\left(T_{H} 3\right)$ cells. $T_{r} 1$ and $T_{H} 3$ cells are implicated in immune responses to foreign antigens in the periphery, alongside $\mathrm{nT}_{\text {reg }}$ cells (22).

While extrathymic generation of $\mathrm{T}_{\text {reg }}$ cells is not as well understood as $\mathrm{nT}_{\text {reg }}$ cell generation, $\mathrm{T}_{\mathrm{r}} 1$ and $\mathrm{T}_{\mathrm{H}} 3$ cells are derived from naïve $\mathrm{T}$ cells in an environment supporting suitable antigenic and cytokine stimulation $(24,29)$. Located in peripheral lymphoid tissue, these cells produce a distinct cytokine profile upon TCR-mediated activation (22). $\mathrm{T}_{\mathrm{r}} 1$ and $\mathrm{T}_{\mathrm{H}} 3$ cells mediate immunosuppression through the secretion of IL-10 and TGF- $\beta 1(21,23,30,31) . \mathrm{T}_{\mathrm{r}} 1$ and $\mathrm{T}_{\mathrm{H}} 3$ cells become significant in peripheral self-tolerance when the pool of selfantigen-specific $\mathrm{nT}_{\text {reg }}$ cells is deficient (31).

\section{$\mathbf{T}_{\text {reg }}$ Cell Singularity}

For the purposes of this review and owing to the fact that definitive comparative research on the subsets is insufficient for precise differentiation, $\mathrm{nT}_{\text {reg }}, \mathrm{T}_{\mathrm{r}} 1$ and $\mathrm{T}_{\mathrm{H}} 3$ cells will be collectively referred to as $\mathrm{T}_{\text {reg }}$ cells.

\section{At One with Nature: Modulating Responses of Allergenic Challenge}

Aberrant immune responses to environmental allergens are relatively common with wide variations in severity and manifestation. Depending on the allergen size and mode of exposure, an atopic individual may experience afflictions ranging from asthma to seasonal allergic rhinitis to atopic dermatitis. 
Atopic allergic sensitization involves the overproduction of IgE against environmental allergens, e.g. grass, house dust mites, pollen and animal proteins $(30,32)$. Allergen-specific $\operatorname{IgE}$, on the surface of mast cells and basophils, upon binding to allergen, triggers the release of histamine and mediators resulting in immediate symptomology (33). Often, patients with allergic diseases have a deficient ability to suppress $\mathrm{T}$ cell responses to allergen by $\mathrm{T}_{\text {reg }}$ cells $(32,34)$.

$\mathrm{T}_{\text {reg }}$ cell's role in the prevention of sensitization to allergens has recently been explored (32). Evidence of significant $\mathrm{T}_{\text {reg }}$ cell suppressive action on $\mathrm{T}_{\mathrm{H}} 2$ cell-mediated immune responses supports the notion that their depletion or functional dysregulation may be responsible for atopic pathology (32).

\section{Allergy}

Seasonal allergic rhinitis, more commonly known as Hay Fever, involves the deposition of allergens on the nasal mucosa followed by an immediate hypersensitivity reaction. Allergens involved, like grass pollen, are typically too large to enter into the lower airways, rendering asthmatic complications unusual. $\mathrm{T}_{\text {reg }}$ cells have the capability to reduce or prevent $\mathrm{T}_{\mathrm{H}} 2$ cell-mediated allergic rhinitis and atopic sensitization disorders $(32,34)$.

Allergen-specific $\mathrm{T}_{\text {reg }}$ cells are also modulators of immune response to dietary allergens and intimately involved in the development of oral tolerance. Karlsson et al. illustrates $\mathrm{T}_{\text {reg }}$ cell functionality in an experiment utilizing children with allergy to cow's milk (35). A majority of the allergic children developed oral tolerance to milk following a period of milk restriction. Development of $\beta$-lactalbumin-specific $\mathrm{T}_{\text {reg }}$ cells, in those children who developed tolerance to cow's milk, was found to be responsible for the newfound tolerance. Induction of tolerance to allergen, via antigen-specific $\mathrm{T}_{\text {reg }}$ cell generation, is noted in individuals encountering pollen, dust mites and other environmental antigens $(2,32)$. This signifies the malleability of immune system response and balance afforded by antigen-specific $\mathrm{T}_{\text {reg }}$ cells $(35,36)$.

Taken altogether, the response of an individual to allergen encounter is dependent on many factors, including the quantity and activity of antigen-specific $\mathrm{T}_{\text {reg }}$ and the $\mathrm{T}_{\mathrm{H}} 2$ effector populations (36).

\footnotetext{
Asthma

Asthma is a chronic airway inflammatory disease triggered by allergic exposure and hallmarked by airway inflammation, bronchial hyperreactivity, lung eosinophilia and excessive $\mathrm{T}_{\mathrm{H}} 2$ cytokine production $(28,34)$.

Inappropriate $\mathrm{T}_{\mathrm{H}} 2$ cell response to inhaled allergens elicits airway inflammation. The complex biosignaling cascade resulting in asthma manifestation is mediated by the over production of IL-4, IL-5, IL-9 and IL-13, which serves to regulate IgE production and to sequester effector cells to the airway. Effector cells that are directed towards airway tissues enhance airway inflammation and hyperresponsiveness through the generation of additional proinflammatory cytokines and
}

autocoids $(32,37)$. In many cases, asthma pathology is due to an excess of $\mathrm{T}_{\mathrm{H}} 2$ cell quantity or activity, leading to a skewing towards a proinflammatory cytokine profile (28).

Mouse models of airway inflammation allow for the examination of allergen-specific $\mathrm{T}_{\text {reg }}$ cells activity in vivo. The transfer of ovalbumin (OVA) peptide-specific $\mathrm{T}_{\text {reg }}$ cells to OVA sensitized mice reduced $\mathrm{T}_{\mathrm{H}} 2$ type cytokine expression in the lungs, airway hyperreactivity and effector cell recruitment. The ameliorative effects were dependent upon IL-10; however, $\mathrm{T}_{\mathrm{H}} 2$ cells were the source of IL-10 secretion, rather than $\mathrm{T}_{\text {reg }}$ cells (34). $\mathrm{T}_{\text {reg }}$ cells may reduce inflammatory response through a contact-dependent manner, e.g. enhancing the secretion of IL-10 by $\mathrm{T}_{\mathrm{H}} 2$ cells.

$\mathrm{T}_{\text {reg }}$ cells aid in the suppression of inflammatory responses to inhaled antigen and are essential for the induction of allergenic tolerance. Administration of inhaled allergen, with prior induction of allergen-specific $\mathrm{T}_{\text {reg }}$ cells, prevents allergen sensitization and airway inflammation upon later exposure. Thus, immunotherapy offers a powerful function based on the modulation of allergen-specific $\mathrm{T}_{\text {reg }}$ cell suppression of $\mathrm{T}_{\mathrm{H}} 2$ responses (32).

\section{Dermatitis}

Atopic dermatitis is a chronic inflammatory skin disorder in which $\mathrm{T}_{\mathrm{H}} 2$ effector cells migrate to the dermis, and under IL-1 2 conditions, become $\mathrm{T}_{\mathrm{H}} 0$ or $\mathrm{T}_{\mathrm{H}} 1$ cells. In atopic individuals, a dysregulation of effector $\mathrm{T}$ cells and an impairment of $\mathrm{T}_{\text {reg }}$ cell suppression are involved in the development of inflammatory pathology (38). While various treatment options exist, including the use of steroids, antihistamines and aggregative factor elimination, an increasing number of patients are finding little relief and are requiring other therapeutic modalities, some of which may be derived from CAM (39).

\section{Throwing Water on the Inflammation: $T_{\text {reg }}$ Cell's Delicate Relations to Infectious Pathology}

To deal with microorganisms, the body has evolved intricate defense mechanisms. The process of pathogen control involves the recruitment of immune system cells to the site of infection. Necessary components include inflammatory cells, cytotoxic $\mathrm{T}$ cells and NK cells. The generation of antigen-specific $\mathrm{T}_{\text {reg }}$ cells is a crucial regulatory element in the immune response to infection by bacteria, parasites, fungi and viruses, as well as the fostering and maintenance of tolerance to non-pathogenic microbes $(21,40)$. Dysregulation of $\mathrm{T}_{\text {reg }}$ cellmediated anti-inflammatory pathways poses potentially great risks to health (41).

Effective immune response to pathogen is often accompanied by a great deal of inflammation. In excess, this inflammation can cause collateral tissue damage and pathology that necessitates the activation and proliferation of pathogenspecific $\mathrm{T}_{\text {reg }}$ cells $(19,21,42-44$; Fig. 1). Conversely, a decrease in defense responsiveness owing to underlying 


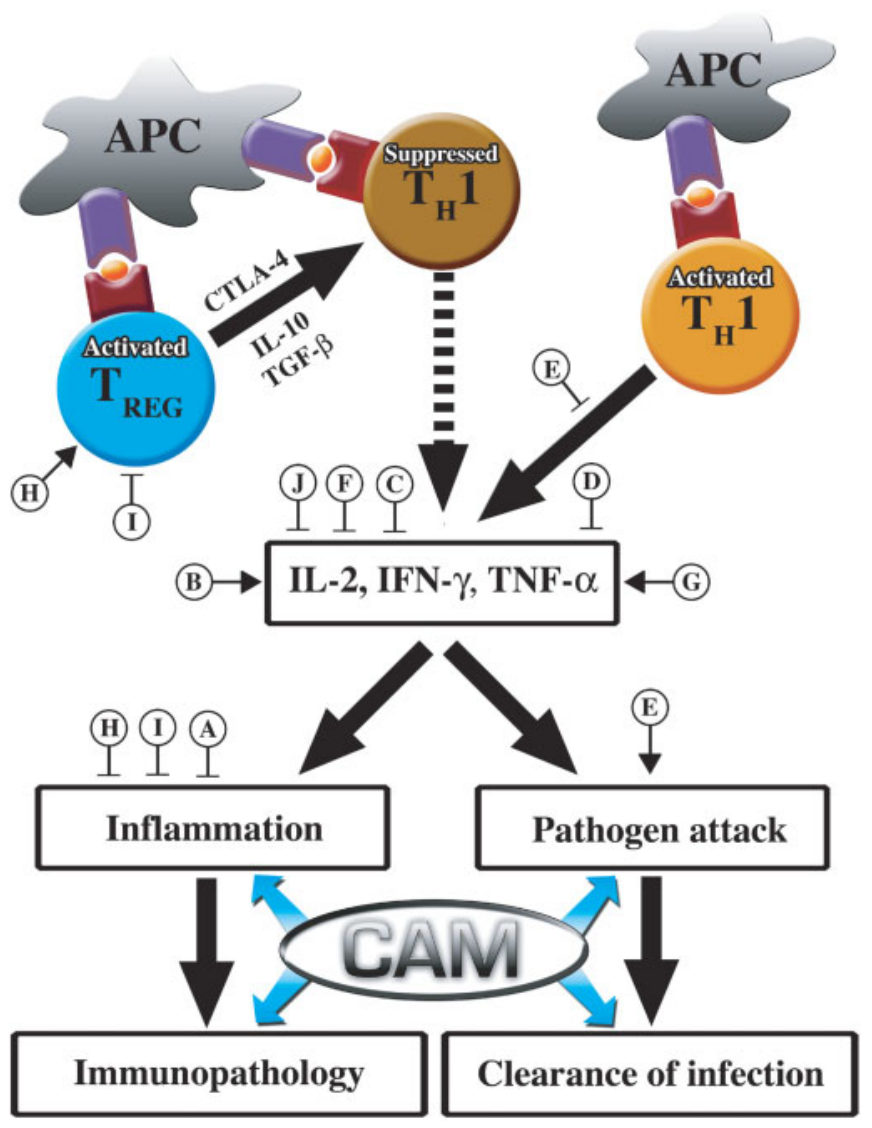

Figure 1. Modulation of $\mathrm{T}_{\mathrm{H}} 1$ cell immune response by $\mathrm{T}_{\text {reg }}$ cells and CAM. Sites of action throughout the $\mathrm{T}_{\mathrm{H}} 1$ cell-mediated inflammatory pathway. A, Brazilian green propolis; B, Ganoderma lucidum; C, P. linteus; D, Piper methysticum; E, Allium sativum; F, (-)-epigallocatechin gallate; G, KRN7000; H, probiotics; I, Staphylococcal superantigen B; J, Ergosterol peroxide.

immunosuppression renders the host susceptible to pathogenic infection and subsequent harm. Depending on a number of variables, a reconstitution of immune system responses or $\mathrm{T}_{\text {reg }}$ cell populations may be necessary in lieu of appropriate antimicrobial or inflammatory therapy.

\section{Bacterial Infections}

IL-10 secreting $\mathrm{T}_{\text {reg }}$ cells attenuate bacterial-induced abnormalities caused by massive inflammation. This immunosuppressive cytokine is imperative for dampening excessive inflammation, owing to $\mathrm{T}_{\mathrm{H}} 1$ responses and increase in TNF$\alpha$ production, while it is potentially detrimental to pathogen attack, thus making the level of IL-10 in sites of inflammation extremely delicate and specific (44).

A variety of bacterial-induced inflammatory diseases ranging from peritonitis from Escherichia coli, to chronic gastritis from Helicobacter pylori and to chronic hepatitis from Helicobacter hepaticus, reinforce a correlation between IL-10 deficiencies and disease severity. To illustrate this, mice with a deficiency in IL-10, upon exposure to Listeria monocytogenes, have a greater severity of brain lesions, because of increased proinflammatory cytokine production in the brain (44-46). In this instance, either specialized $\mathrm{T}_{\text {reg }}$ cells or their IL-10 secretions help to limit $\mathrm{T}_{\mathrm{H}} 1$ cell-mediated inflammation and damage during infection.

Recognition of hazardous microbes, allergens and toxins as pathogenic agents activates the gastrointestinal immune system. Antigen-specific $\mathrm{T}_{\text {reg }}$ cells, which mediate oral tolerance to commensal microbes, differentiate between harmless inhabitants of the gut and pathogens. A break in the development or maintenance of oral tolerance may result in an astounding array of detrimental inflammatory disorders, including inflammatory bowl disease (IBD) and colitis.

IBD and colitis are conditions in which the immune system of patients reacts excessively to indigenous intestinal bacteria. $\mathrm{T}_{\text {reg }}$ cell depletion in these disorders effectively breaches tolerance and allows for massive inflammation in the gut. In vivo transfer of $\mathrm{T}_{\text {reg }}$ cells suppresses disease development, through IL-10, TGF- $\beta$ and CTLA-4-dependent mechanisms (21).

Colonization of gastric and duodenal mucosa by $H$. pylori induces strong immune responses involving innate immune system cells as well as $H$. pylori-specific T and B cells (27). $\mathrm{T}_{\text {reg }}$ cells dampen the immune response to $H$. pylori, effectively limiting acute infection-induced pathology, at the cost of bacterial persistence and long-term pathology, i.e. chronic infection (27). Prevention of inflammation via IL-10 and TGF- $\beta$ may prove useful in the control of $H$. pylori infection (21).

Interestingly, varieties of bacteria including Mycobacterium tuberculosis, Yersinia entercolitica and Bordetella pertussis induce production of IL-10 by macrophages. This cytokine manipulation efficiently triggers immunosuppression and attenuates bacterial attack, by means of inducing development of IL-10 secreting $\mathrm{T}_{\text {reg }}$ cells $(46,47)$.

The appropriate balance between inflammation and bacterial destruction so that the body accrues minimal tissue damage while putting up adequate host defense as well as development of tolerance to commensals are essential roles of IL-10 secreting $\mathrm{T}_{\text {reg }}$ cells. Thus, they pose a promising target for the suppression of extreme inflammation and tissue damage during bacterial exposure or infection. It is important to note that different clinical outcomes may result from $\mathrm{T}_{\text {reg }}$ cell activation status.

\section{Fungal Infections}

$\mathrm{T}_{\text {reg }}$ cell activation limits inflammatory pathology induced by fungal infection but compromises fungal clearance. Pneumocystis carinii and Candida albicans are used in models to ascertain $\mathrm{T}_{\text {reg }}$ cell function. Infection of $\mathrm{T}_{\text {reg }}$ cell deficient mice with $P$. carinii yields fatal pulmonary inflammation, with damage owing to $\mathrm{CD} 4^{+}$effector $\mathrm{T}$ cells. $\mathrm{T}_{\text {reg }}$ cell infusion prevents inflammation and disease development at the cost of increased pathogen load $(19,21,48-50)$. Similarly, $\mathrm{T}_{\text {reg }}$ cell depletion renders adequate control of $C$. albicans infection 
while allowing for large-scale gastrointestinal inflammation to ensue (21).

\section{Parasitic Infections}

IL-10 or TGF- $\beta$ secreting $\mathrm{T}_{\text {reg }}$ cells have great utility in the balance between parasite clearance and induced immunopathology, as seen in malarial, Plasmodium chabaudi and L. major infections.

The severity of malarial infection directly correlates to the ratio of TGF- $\beta$ and IL-10 levels to TNF- $\alpha$ levels, i.e. a greater proportion of suppressive cytokines attenuates severity of infection-induced inflammation. IL-10-deficient mice, infected with $P$. chabaudi, maintain severe infection and massive inflammatory responses resulting in significant host damage (44,51-53). In the case of L. major infection, removal of $\mathrm{T}_{\text {reg }}$ cells results in the effective parasite clearance, however bad lesions and a robust $\mathrm{T}_{\mathrm{H}} 2$ response ensue $(19,21,27,54)$. This substantiates the importance of TGF- $\beta$ and IL-10 secreting $\mathrm{T}_{\text {reg }}$ cells in controlling parasitic infection and pathology.

Various parasites that have adapted to $\mathrm{T}_{\text {reg }}$ cell host-defense mechanisms have the ability to modulate $\mathrm{T}_{\text {reg }}$ cell cytokine production and activation (55-57). Therefore, the role of $\mathrm{T}_{\text {reg }}$ cells in inflammatory pathology and pathogen clearance may vary significantly between individual parasitic infectious agents.

\section{Viral Infections}

$\mathrm{T}_{\text {reg }}$ cells reduce the severity of immune-mediated inflammatory lesions in viral-induced diseases through the suppression of pathogenic $\mathrm{CD}^{+} \mathrm{T}$ cell activity and the limitation of inflammatory cell sequestration.

Chronic hepatitis $\mathrm{C}$ virus infection results in massive hepatic inflammation and damage. In liver biopsies, there is an inverse correlation between peripheral $\mathrm{T}_{\text {reg }}$ cells and histological inflammatory score (21). $\mathrm{T}_{\text {reg }}$ cells, specifically those secreting IL-10, are essential for the attenuation of such organ detriment.

Theiler's virus induces murine encephalomyelitis, a $\mathrm{T}_{\mathrm{H}} 1$ cell-mediated inflammatory disease of the central nervous system, and provides a model of human multiple sclerosis from which exploration of $\mathrm{T}_{\text {reg }}$ cell functionality in autoimmune detriment is possible. B cell proliferation and autoantibody production, in some viral infections, plays a major role in the development of viral-induced autoimmunity (51,58). Infected mice may experience acute encephalomyelitis or chronic demyelinating disease depending on the strain. Virusspecific $\mathrm{T}_{\text {reg }}$ cells sufficiently suppress this aberrant $\mathrm{CD} 4^{+}$ $\mathrm{T}_{\mathrm{H}} 1$ cell-mediated response $(59)$. $\mathrm{T}_{\text {reg }}$ cell modulation of reactions to self, regardless of causation, holds promising implications for a broad spectrum of deleterious autoimmune diseases.

During chronic viral infections, $\mathrm{T}_{\text {reg }}$ cells are beneficial to the host by maintaining a balance between efficient viral defense and inflammation, while preventing the induction of autoimmune disorders (56-63). Similar to other pathogens, certain viruses, like HIV, have developed mechanisms that directly affect $\mathrm{T}_{\text {reg }}$ cell function, resulting in reduced antiviral response and increased viral persistence (62-65).

\section{The Maginot Line: $\mathrm{T}_{\text {reg }}$ Cell's Blockade of Allergic and Infectious Immune Responses}

Innovative research and subsequent elucidation of $\mathrm{T}_{\text {reg }}$ cell involvement in various atopic and infectious pathologies opens up numerous avenues for ameliorative therapies while describing mechanisms of disease pathogenesis. It is apparent that the $\mathrm{T}_{\text {reg }}$ cell quantity and activation state are integral and equally important factors in the development and maintenance of inflammatory immunopathology (36).

$\mathrm{T}_{\text {reg }}$ cell involvement in immune response to pathogens is delicate since $\mathrm{T}_{\text {reg }}$ cells actively suppress immunopathology during infection, while concomitantly supporting persistence of infection during chronic disease. Aberrant modulation of immune responses by $\mathrm{T}_{\text {reg }}$ cells may be owing to inappropriate quantity or functionality of $\mathrm{T}_{\text {reg }}$ cells. Excessive immune suppression results in enhanced pathogen survival, through clearance inhibition, which may lead to long-term persistence, pathogen damage and increased potential for transmission (21). On the other hand, depressed $\mathrm{T}_{\text {reg }}$ cell activity allows little control of inflammatory responses resulting in collateral tissue damage $(21,41)$. A balance between effector $\mathrm{T}$ and $\mathrm{T}_{\text {reg }}$ cell responses in sites of chronic infection may allow parasite survival in host while maintaining host immune memory and control of the pathogen (44).

Pathogens are evolving self-serving strategies to increase survival potential, through the establishment of favorable conditions for $\mathrm{T}_{\text {reg }}$ cell priming, recruitment and survival (21). Certain pathogens and their products, e.g. Staphylococcal superantigen B, HTLV-1 and HIV, directly target and modulate $\mathrm{T}_{\text {reg }}$ cell function (2). Evolved pathogen mechanisms for $\mathrm{T}_{\text {reg }}$ cells manipulation underscores the power and utility that $\mathrm{T}_{\text {reg }}$ cells hold and presents another means for medical treatment of related diseases, e.g. implementation of means to effectively antagonize pathways in which pathogens directly modulate $\mathrm{T}_{\text {reg }}$ cell functioning.

Increased research is necessary in order to determine $T_{\text {reg }}$ cell functioning in relation to individual allergic and pathogen induced disease states. This will afford CAM researchers insight into the appropriate means of approaching a variety of human disorders with respect to $\mathrm{T}_{\text {reg }}$ cells.

$\mathrm{T}_{\text {reg }}$ cell's essential role in the management of allergy and infection has been detailed using specific allergens or pathogens as examples. Harmony between regulatory and effector arms of the immune system is a necessity for good health. $\mathrm{T}_{\text {reg }}$ cell intricacy and specificity to individual allergens or pathogens impels further research and highlights $T_{\text {reg }}$ cells overall importance to human health and CAM. The conceptual framework laid down is consistent with various disease states, including autoimmunity and tumor pathogenesis, which will be a futile subject. 


\section{Conflict of Interest}

Aristo Vodjani is co-owner of Immunosciences Lab. Inc. He declares no conflict of interest.

\section{References}

1. Vojdani A, Erde J. Regulatory T cells, a potent immunoregulatory target for CAM researchers: the ultimate antagonist (I). Evid Based Complement Altern Med 2006;3:25-30.

2. Chatila TA. Role of regulatory T cells in human diseases. $J$ Allergy Clin Immunol 2005;116:949-59.

3. Shimazawa M, Chikamatsu S, Morimoto N, Mishima S, Nagai H, Hara H. Neuroprotection by Brazilian green propolis against in vitro and in vivo ischemic neuronal damage. Evid Based Complement Alternat Med 2005;2:201-7.

4. Kuo MC, Weng CY, Ha CL, Wu MJ. Ganoderma lucidum mycelia

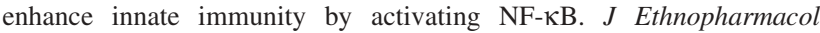
2006; 103:217-22.

5. Lindequist U, Niedermeyer TH, Julich WD. The pharmacological potential of mushrooms. Evid Based Complement Alternat Med 2005;2: 285-99.

6. Inagaki N, Shibata T, Itoh T, Suzuki T, Tanaka H, Nakamura T, et al. Inhibition of IgE-dependent mouse triphasic cutaneous reaction by a boiling water fraction separated from mycelium of Phellinus linteus. Evid Based Complement Alternat Med 2005;2:369-74.

7. Folmer F, Blasius R, Morceau F, Tabudravu J, Dicato M, Jaspars M, Diederich M. Inhibition of TNFalpha-induced activation of nuclear factor $\kappa \mathrm{B}$ by kava (Piper methysticum) derivatives. Biochem Pharmacol 2006; 71(8):1206-18.

8. Ghazanfari T, Hassan ZM, Khamesipour A. Enhancement of peritoneal macrophage phagocytic activity against Leishmania major by garlic (Allium sativum) treatment. J Ethnopharmacol 2006;103:333-7.

9. Watson JL, Vicario M, Wang A, Moreto M, McKay DM. Immune cell activation and subsequent epithelial dysfunction by Staphylococcus enterotoxin B is attenuated by the green tea polyphenol (-)-epigallocatechin gallate. Cell Immunol 2005;237:7-16.

10. Smits HH, Engering A, van der Kleij D, de Jong EC, Schipper K, van Capel TM, et al. Selective probiotic bacteria induce IL-10-producing regulatory $\mathrm{T}$ cells in vitro by modulating dendritic cell function through dendritic cell-specific intercellular adhesion molecule 3-grabbing nonintegrin. J Allergy Clin Immunol 2005;115:1260-7.

11. Rautava S, Kalliomaki M, Isolauri E. New therapeutic strategy for combating the increasing burden of allergic disease: Probiotics-A Nutrition, Allergy, Mucosal Immunology and Intestinal Microbiota (NAMI) Research Group report. J Allergy Clin Immunol 2005;116:31-7.

12. Kim H, Kwack K, Kim DY, Ji GE. Oral probiotic bacterial administration suppressed allergic responses in an ovalbumin-induced allergy mouse model. FEMS Immunol Med Microbiol 2005;45:259-67.

13. Tien MT, Girardin SE, Regnault B, Le Bourhis L, Dillies MA, Coppee JY, et al. Anti-inflammatory effect of Lactobacillus casei on Shigella-infected human intestinal epithelial cells. J Immunol 2006;176:1228-37.

14. Di Giacinto C, Marinaro M, Sanchez M, Strober W, Boirivant M Probiotics ameliorate recurrent Th1-mediated murine colitis by inducing IL-10 and IL-10-dependent TGF- $\beta$-bearing regulatory cells. J Immunol 2005;174:3237-46.

15. Goleva E, Cardona ID, Ou LS, Leung DY. Factors that regulate naturally occurring T regulatory cell-mediated suppression. J Allergy Clin Immunol 2005;116:1094-100.

16. Wen MC, Wei CH, Hu ZQ, Srivastava K, Ko J, Xi ST, et al. Efficacy and tolerability of anti-asthma herbal medicine intervention in adult patients with moderate-severe allergic asthma. J Allergy Clin Immunol 2005;116: 517-24.

17. Engler RJ. Alternative and complementary medicine: a source of improved therapies for asthma? A challenge for redefining the specialty? J Allergy Clin Immunol 2000;106:627-9.

18. Haefner B. Drugs from the deep: marine natural products as drug candidates. Drug Discov Today 2003;8:536-44.

19. Fehervari Z, Sakaguchi S. Regulatory $T$ cells. In: Lotze MT, Thompson AW (eds). Measuring Immunity. Oxford: Elsevier, 2005, 322-35.

20. Fehervari Z, Sakaguchi S. CD4+ Tregs and immune control. J Clin Invest 2004;114:1209-17.
21. Belkaid Y, Rouse BT. Natural regulatory $\mathrm{T}$ cells in infectious disease. Nat Immunol 2005;6:353-60.

22. Chattopadhyay S, Mehrotra S, Chhabra A, Hegde U, Mukherji B, Chakraborty NG. Effect of CD4+CD25+ and CD4+CD25- T regulatory cells on the generation of cytolytic $\mathrm{T}$ cell response to a self but human tumor-associated epitope in vitro. J Immunol 2006;176:984-90.

23. Maggi E, Cosmi L, Liotta F, Romagnani P, Romagnani S, Annunziato F. Thymic regulatory T cells. Autoimmun Rev 2005;4:579-86.

24. Chiappelli F. The molecular immunology of mucositis: implications for evidence-based research in alternative and complementary palliative treatments. Evid Based Complement Alternat Med 2005;2:489-94.

25. Montagnoli C, Fallarino F, Gaziano R, Bozza S, Bellocchio S, Zelante T, et al. Immunity and tolerance to Aspergillus involve functionally distinct regulatory $\mathrm{T}$ cells and tryptophan catabolism. J Immunol 2006;176: 1712-23.

26. Bousso P. Lymph node choreography: $\mathrm{T}_{\text {reg }}$ cells join the dance. Nat Immunol 2006;7:11-3.

27. Lundgren A, Stromberg E, Sjoling A, Lindholm C, Enarsson K, Edebo A, et al. Mucosal FOXP3-expressing CD4+CD25 high regulatory T cells in Helicobacter pylori-infected patients. Infect Immun 2005;73:523-31.

28. Seroogy CM, Gern JE. The role of T regulatory cells in asthma. J Allergy Clin Immunol 2005;116:996-9.

29. Skapenko A, Kalden JR, Lipsky PE, Schulze-Koops H. The IL-4 receptor alpha-chain-binding cytokines, IL-4 and IL-13, induce forkhead box $\mathrm{P} 3$-expressing CD25+CD4+ regulatory $\mathrm{T}$ cells from CD25-CD4+ precursors. J Immunol 2005;175:6107-16.

30. Ostroukhova M, Seguin-Devaux C, Oriss TB, Dixon-McCarthy B, Yang L, Ameredes BT, et al. Tolerance induced by inhaled antigen involves CD4 $+\mathrm{T}$ cells expressing membrane-bound TGF- $\beta$ and FOXP3. J Clin Invest 2004;114:28-38.

31. Valmori D, Merlo A, Souleimanian NE, Hesdorffer CS, Ayyoub M. A peripheral circulating compartment of natural naive CD4 Tregs. J Clin Invest 2005;115:1953-62.

32. Robinson DS, Larche M, Durham SR. Tregs and allergic disease. J Clin Invest 2004;114:1389-97.

33. Bellavite P, Conforti A, Pontarollo F, Ortolani R. Immunology and homeopathy. 2. Cells of the immune system and inflammation. Evid Based Complement Altern Med 2006;3:13-24.

34. Kearley J, Barker JE, Robinson DS, Lloyd CM. Resolution of airway inflammation and hyperreactivity after in vivo transfer of CD4+CD25+ regulatory $\mathrm{T}$ cells is interleukin 10 dependent. J Exp Med 2005;202: $1539-47$.

35. Karlsson MR, Rugtveit J, Brandtzaeg P. Allergen-responsive $\mathrm{CD} 4+\mathrm{CD} 25+$ regulatory $\mathrm{T}$ cells in children who have outgrown cow's milk allergy. J Exp Med 2004;199:1679-88.

36. Maizels RM. Infections and allergy-helminths, hygiene and host immune regulation. Curr Opin Immunol 2005;17:656-61.

37. Bochner BS, Busse WW. Allergy and asthma. J Allergy Clin Immunol 2005;115:953-9.

38. Verhagen J, Akdis M, Traidl-Hoffmann C, Schmid-Grendelmeier P, Hijnen D, Knol EF, et al. Absence of T-regulatory cell expression and function in atopic dermatitis skin. J Allergy Clin Immunol 2006;117: $176-83$.

39. Kobayashi H, Takahashi K, Mizuno N, Kutsuna H, Ishii M. An alternative approach to atopic dermatitis: part I-case-series presentation. Evid Based Complement Altern Med 2004;1:49-62.

40. Kingston H, Mills G. Regulatory T cells: friend or foe in immunity to infection? Nat Rev Immunol 2004;4:841-55.

41. Haddad PS, Azar GA, Groom S, Boivin M. Natural health products, modulation of immune function and prevention of chronic diseases. Evid Based Complement Alternat Med 2005;2:513-20.

42. Caramalho I, Lopes-Carvalho T, Ostler D, Zelenay S, Haury M, Demengeot J. Regulatory $\mathrm{T}$ cells selectively express toll-like receptors and are activated by lipopolysaccharide. J Exp Med 2003;197: 403-11.

43. Muthukuru M, Jotwani R, Cutler CW. Oral mucosal endotoxin tolerance induction in chronic periodontitis. Infect Immun 2005;73:687-94.

44. O'Garra A, Vieira PL, Vieira P, Goldfeld AE. IL-10-producing and naturally occurring CD4+ Tregs: limiting collateral damage. J Clin Invest 2004; 114:1372-8.

45. Sewnath ME, Olszyna DP, Birjmohun R, ten Kate FJ, Gouma DJ, van Der Poll T. IL-10-deficient mice demonstrate multiple organ failure and increased mortality during Escherichia coli peritonitis despite an accelerated bacterial clearance. J Immunol 2001;166:6323-31. 
46. Kullberg MC, Rothfuchs AG, Jankovic D, Caspar P, Wynn TA, Gorelick PL, et al. Helicobacter hepaticus-induced colitis in interleukin 10-deficient mice: cytokine requirements for the induction and maintenance of intestinal inflammation. Infect Immun 2001;69:4232-41.

47. McGuirk P, McCann C, Mills KHG. Pathogen-specific T regulatory 1 cells induced in the respiratory tract by a bacterial molecule that stimulates interleukin-10 production by dendritic cells: a novel strategy for evasion of protective $\mathrm{T}$ helper type 1 responses by Bordetella pertussis. J Exp Med 2002;195:221-31.

48. Hori S, Carvalho TL, Demengeot J. CD25+CD4+ regulatory T cells suppress CD4+ $\mathrm{T}$ cell-mediated pulmonary hyperinflammation driven by Pneumocystis carinii in immunodeficient mice. Eur J Immunol 2002;32: 1282-91.

49. Montagnoli C, Bacci A, Bozza S, Gaziano R, Mosci P, Sharpe AH, et al. $\mathrm{B} 7 / \mathrm{CD} 28$-dependent $\mathrm{CD} 4+\mathrm{CD} 25+$ regulatory $\mathrm{T}$ cells are essential components of the memory-protective immunity to Candida albicans. J Immunol 2002;169:6298-308.

50. Netea MG, Sutmuller R, Hermann C, Van der Graaf CA, Van der Meer JW, van Krieken JH, et al. Toll-like receptor 2 suppresses immunity against Candida albicans through induction of IL-10 and regulatory T cells. J Immunol 2004;172:3712-8.

51. May J, Lell B, Luty AJ, Meyer CG, Kremsner PG. Plasma interleukin-10 tumor necrosis factor TNF- $\alpha$ ratio is associated TNF promoter variants and predicts malarial complications. $J$ Infect Dis 2000;182:1570-3.

52. Othoro C, Lal AA, Nahlen B, Koech D, Orago AS, Udhayakumar V. A low interleukin-10 tumor necrosis factor TNF- $\alpha$ ratio is associated with malaria anemia in children residing in a holoendemic malaria region in western Kenya. J Infect Dis 1999;179:279-82.

53. Li C, Corraliza I, Langhorne J. A defect in interleukin-10 leads to enhanced malarial disease in Plasmodium chabaudi chabaudi infection in mice. Infect Immun 1999;67:4435-42.

54. Battaglia M, Gregori S, Bacchetta R, Roncarolo MG. Tr1 cells: from discovery to their clinical application. Semin Immunol 2006;18:120-7.

55. Omer FM, Riley EM. Transforming growth factor- $\beta$ production is inversely correlated with severity of murine malaria infection. $J$ Exp Med 1998;188:39-48.

56. Omer FM, de Souza JB, Riley EM. Differential induction of TGF- $\beta$ regulates proinflammatory cytokine production and determines the outcome of lethal and nonlethal Plasmodium yoelii infections. J Immunol $2003 ; 171: 5430-6$.
57. Hesse M, Piccirillo CA, Belkaid Y, Prufer J, Mentink-Kane M, Leusink M, et al. The pathogenesis of schistosomiasis is controlled by cooperating IL-10-producing innate effector and regulatory $\mathrm{T}$ cells. J Immunol 2004;172:3157-66.

58. Accapezzato D, Francavilla V, Paroli M, Casciaro M, Chircu LV, Cividini A, et al. Hepatic expansion of a virus-specific regulatory $\mathrm{CD} 8+\mathrm{T}$ cell population in chronic hepatitis $\mathrm{C}$ virus infection. J Clin Invest 2004;113:963-72.

59. Haynes LM, Vanderlugt CL, Dal Canto MC, Melvold RW, Miller SD. $\mathrm{CD} 8+\mathrm{T}$ cells from Theiler's virus-resistant BALB/cByJ mice downregulate pathogenic virus-specific $\mathrm{CD} 4+\mathrm{T}$ cells. $J$ Neuroimmunol 2000;106:43-52.

60. Suvas S, Kumaguru U, Pack CD, Lee S, Rouse BT. CD4+CD25+ T cells regulate virus-specific primary and memory $\mathrm{CD} 8+\mathrm{T}$ cell responses. J Exp Med 2003;198:889-901.

61. Suvas S, Azkur AK, Kim BS, Kumaguru U, Rouse BT. CD4+CD25+ regulatory $\mathrm{T}$ cells control the severity of viral immunoinflammatory lesions. J Immunol 2004;172:4123-32.

62. Sugimoto K, Ikeda F, Stadanlick J, Nunes FA, Alter HJ, Chang KM. Suppression of $\mathrm{HCV}$-specific $\mathrm{T}$ cells without differential hierarchy demonstrated in vivo in persistent HCV infection. Hepatology 2003;38: $1437-48$.

63. Kinter AL, Hennessey M, Bell A, Kern S, Lin Y, Daucher M, et al. $\mathrm{CD} 25+\mathrm{CD} 4+$ regulatory $\mathrm{T}$ cells from the peripheral of asymptomatic HIV-infected individuals regulate CD4+ and CD8 + HIV-specific T cell immune responses in vitro and are associated with favorable clinical markers of disease status. J Exp Med 2004;200:331-43.

64. Aandahl EM, Michaelsson J, Moretto WJ, Hecht FM, Nixon DF. Human $\mathrm{CD} 25+\mathrm{CD} 4+$ regulatory $\mathrm{T}$ cells control $\mathrm{T}$ cell responses to human immunodeficiency virus and cytomegalovirus antigens. J Virol 2004;78: 2454-9.

65. Iwashiro M, Messer RJ, Peterson KE, Stromnes IM, Sugie T, Hasenkrug KJ. Immunosuppression by $\mathrm{CD} 4+$ regulatory $\mathrm{T}$ cells induced by chronic retroviral infection. Proc Natl Acad Sci USA 2004; 98:9226-30.

Received March 15, 2006; accepted March 16, 2006 


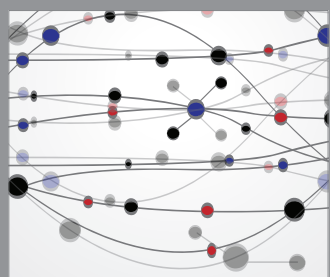

The Scientific World Journal
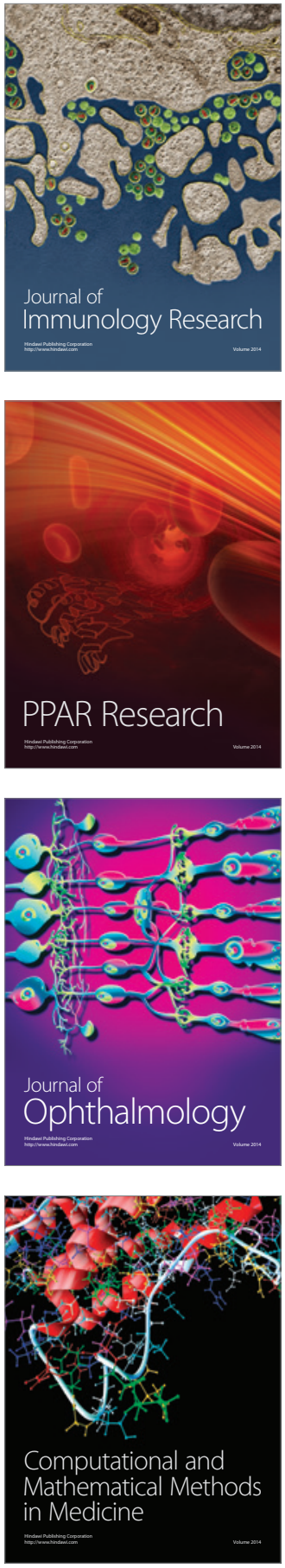

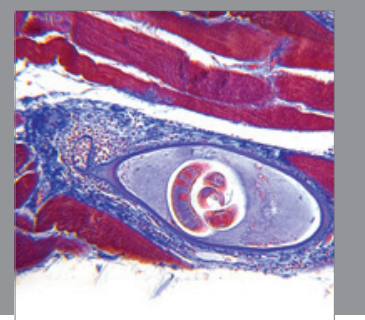

Gastroenterology

Research and Practice
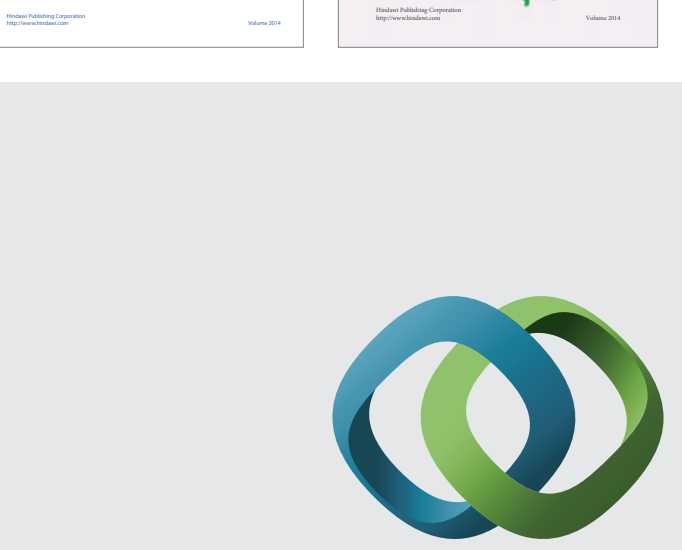

\section{Hindawi}

Submit your manuscripts at

http://www.hindawi.com
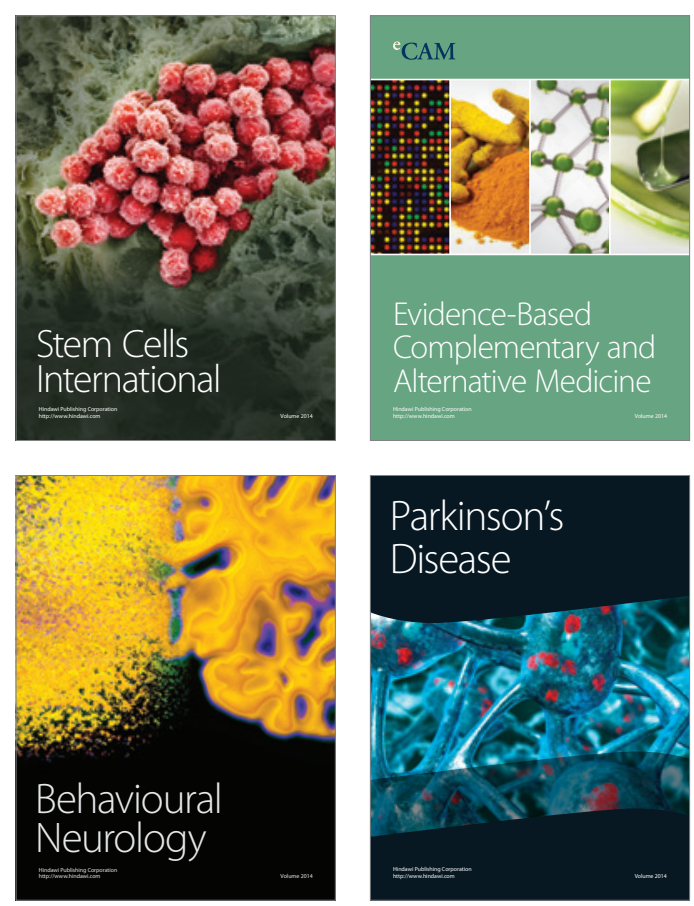

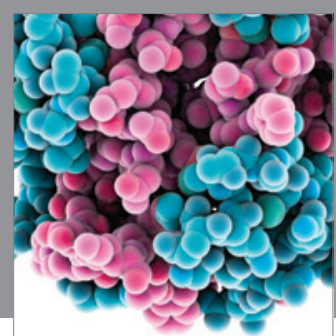

Journal of
Diabetes Research

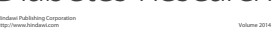

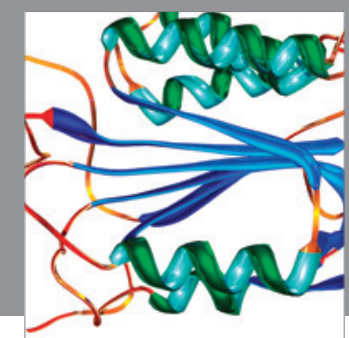

Disease Markers
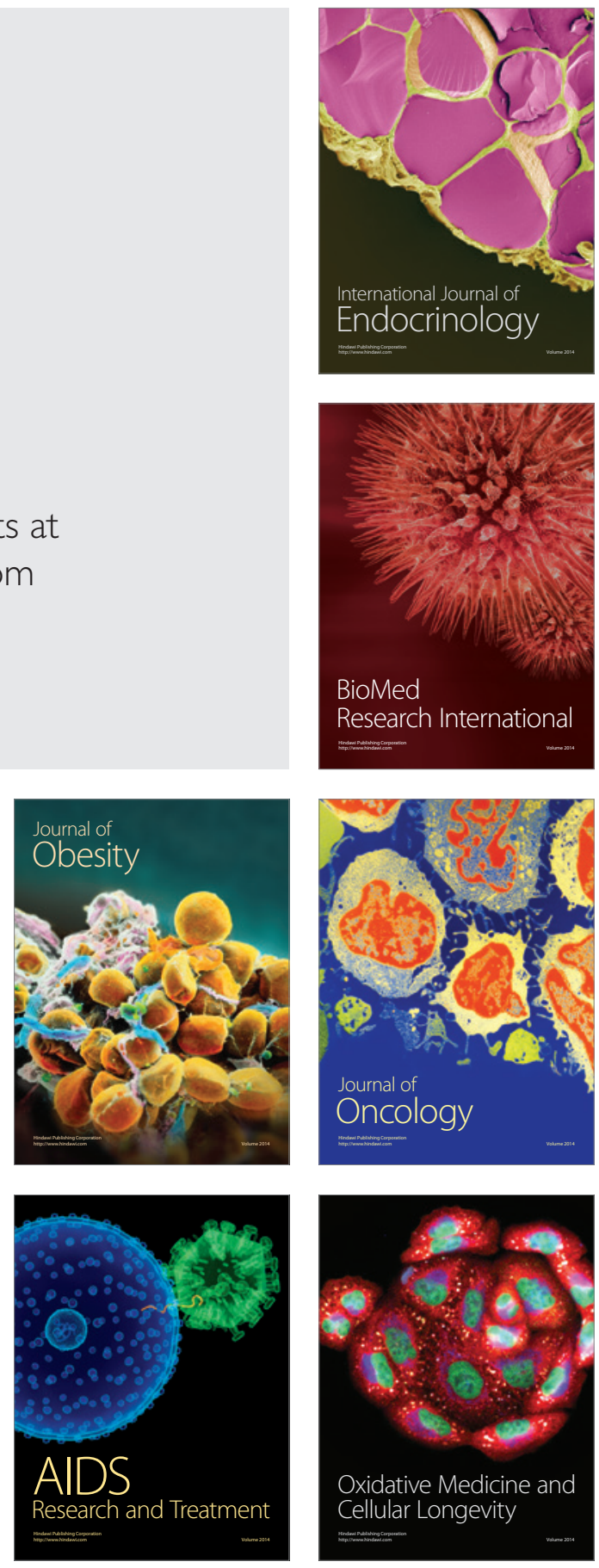